\title{
Correction to: Determinants of the quality of care relationships in long-term care - a systematic review
}

\author{
Aukelien Scheffelaar ${ }^{1,2^{*}}$, Nanne Bos ${ }^{1}$, Michelle Hendriks ${ }^{3}$, Sandra van Dulmen ${ }^{1,2,4}$ and Katrien Luijkx ${ }^{5}$
}

\section{Correction to: BMC Health Serv Res (2018) 18:903 \\ https://doi.org/10.1186/s12913-018-3704-7}

In the original publication of this article [1], there is a layout mistake in the column "McCloughen et al. (2011)" of Table 2.

The corrected column should be:

\begin{tabular}{|c|c|c|c|c|c|c|}
\hline Authors (year) & Aim & Data collection & Study population & Perspective 1 & $\begin{array}{l}\text { Client } \\
\text { group } 2\end{array}$ & $\begin{array}{l}\text { Determinants described } \\
\text { (level) }\end{array}$ \\
\hline $\begin{array}{l}\text { McCloughen } \\
\text { et al. (2011) }\end{array}$ & $\begin{array}{l}\text { To identify whether } \\
\text { consumers and nurses } \\
\text { in a mental health } \\
\text { rehabilitation setting } \\
\text { shared common } \\
\text { understandings, } \\
\text { attitudes, values, and } \\
\text { experiences of nurse-- } \\
\text { consumer collaboration. }\end{array}$ & $\begin{array}{l}\text { focus groups and a } \\
\text { survey for consumers } \\
\text { and a survey for } \\
\text { nurses. }\end{array}$ & $\begin{array}{l}\text { Consumers of inpatient } \\
\text { rehabilitation service of } \\
\text { a public psychiatric } \\
\text { hospital. The research } \\
\text { setting comprised one } \\
\text { locked and one open } \\
\text { ward and five } \\
\text { residential-type com- } \\
\text { plexes. Consumers re- } \\
\text { ceived less intensive } \\
\text { support from nurses and } \\
\text { were close to discharge } \\
\text { into community accom- } \\
\text { modation. Three focus } \\
\text { group were held with } \\
13 \text { consumers from four } \\
\text { residential-type com- } \\
\text { plexes and three focus } \\
\text { groups were held with } \\
13 \text { nurses. Thereafter, } \\
\text { surveys were completed } \\
\text { by } 34 \text { nursing staff and } \\
18 \text { consumers. }\end{array}$ & $C \& P$ & $M$ & $\begin{array}{l}\text { Client: - Abilities - Attitude } \\
\text { (open to professional) - } \\
\text { Strategic adapting } \\
\text { behaviour } \\
\text { Professional: - Attitude } \\
\text { (open to client, respectful) - } \\
\text { Dependable - Focus on } \\
\text { individual client - Listen - } \\
\text { Professional competences } \\
\text { (communication) - Working } \\
\text { in a team } \\
\text { Between client and } \\
\text { professional: - Equality } \\
\text { (collaboration) - Social } \\
\text { interaction (open } \\
\text { communication) - Hierarchy } \\
\text { - Trust } \\
\text { Contextual: - Hierarchy - } \\
\text { Time (workload, lack of } \\
\text { backup) }\end{array}$ \\
\hline
\end{tabular}

The original article has been corrected.

\footnotetext{
* Correspondence: A.Scheffelaar@nivel.nl

${ }^{1}$ Nivel (Netherlands Institute for Health Services Research), PO Box 1568, 3500 BN Utrecht, The Netherlands

${ }^{2}$ Department of Primary and Community Care, Radboud university medical center, Radboud Institute for Health Sciences, Nijmegen, The Netherlands Full list of author information is available at the end of the article
}

(c) The Author(s). 2019 Open Access This article is distributed under the terms of the Creative Commons Attribution 4.0 International License (http://creativecommons.org/licenses/by/4.0/), which permits unrestricted use, distribution, and reproduction in any medium, provided you give appropriate credit to the original author(s) and the source, provide a link to the Creative Commons license, and indicate if changes were made. The Creative Commons Public Domain Dedication waiver (http://creativecommons.org/publicdomain/zero/1.0/) applies to the data made available in this article, unless otherwise stated. 


\section{Author details}

${ }^{1}$ Nivel (Netherlands Institute for Health Services Research), PO Box 1568, 3500

BN Utrecht, The Netherlands. ${ }^{2}$ Department of Primary and Community Care, Radboud university medical center, Radboud Institute for Health Sciences,

Nijmegen, The Netherlands. ${ }^{3}$ Reinier van Arkel, Den Bosch, The Netherlands. ${ }^{4}$ Faculty of Health and Social Sciences, University of South-Eastern Norway,

Drammen, Norway. ${ }^{5}$ Tilburg School of Social and Behavioral Sciences, Tranzo, Scientific Center for Care and Welfare, Tilburg University, Tilburg, The Netherlands.

Published online: 08 July 2019

\section{Reference}

1. Scheffelaar A, et al. Determinants of the quality of care relationships in longterm care - a systematic review. BMC Health Serv Res. 2018;18:903. 